\title{
NOTAS SOBRE O APARECIMENTO DA NOÇÃO DE VESTÍGIO EM WALTER BENJAMIN
}

Priscilla Stuart da Silva

\begin{abstract}
RESUMO
Neste artigo, apresenta-se uma leitura acerca da noção de vestígio (Spur) em Walter Benjamin, no ensaio Paris do Segundo Império (Das Paris des Second Empire bei Baudelaire) e em alguns arquivos das Passagens (Das Passagen-Werk). Nos ensaios citados, pelas figuras alegóricas do trapeiro e do detetive, há uma caracterização da imagem do humano na cidade moderna após o surgimento das massas nas metrópoles. O vestígio, noção inspirada em um poema de Brecht, é interpretado como o fim de uma ideia de humano em consequência das experiências de choque (Erfahrung des Schocks) surgidas das sociedades industrializadas. Partindo para seu diagnóstico da realidade em Experiência e pobreza (Erfahrung und Armut), percebe-se que as análises de Benjamin revelam a própria condição humana desapropriada de sua individualidade nas sociedades modernas. Deste modo, constata-se, com o advento das multidões, 0 aparecimento do vestígio, consequência da redução da experiência (Erfahrung) humana, convertida em vivência (Erlebnis) e transformada, por sua vez, em miséria existencial. $O$ futuro dessa história é o advento de uma nova subjetividade, a do novo homem.
\end{abstract}

Palavras-chave: Vestígio. Trapeiro. Detetive. Modernidade

\section{NOTES ON THE APPEARANCE OF THE NOTION OF VESTIGE IN WALTER BENJAMIN}

\begin{abstract}
In this article, we present a reading on the notion of vestige (Spur) in Walter Benjamin's essays Paris of the Second Empire (Das Paris des Second Empire bei Baudelaire) and the Arcades Project (Das Passagen-Werk). In the mentioned essays, by means of the allegorical figures of the trapper and the detective, there is a characterization of the human's image in the modern city after the emergence of the masses in the metropolis. The vestige, a notion inspired in a Brecht's poem, is interpreted as the end of an idea of the human because of the experiences of shock (Erfahrung des Schocks) arising from industrialized societies. Starting from his diagnosis of the reality in Experience and Poverty (Erfahrung und Armut), we perceive that Benjamin's analyzes reveal the very human condition expropriated of its individuality within the modern societies. In this way, with the advent of the multitudes, the rising of the vestige, a consequence of the decrease of the human experience (Erfahrung), converted into impoverished experience (Erlebnis) and transformed, in turn, into existential misery. The future of this history is the advent of a new subjectivity, that of the new man.
\end{abstract}

Keywords: Vestige. Trapper. Detective. Modernity 


\title{
INTRODUÇÃO
}

\section{A dialética do declínio da aura e o aparecimento do vestígio}

\begin{abstract}
O que chamamos progresso está enclausurado em cada terra e desaparece com ela. Sempre e em todo lugar, no campo terrestre, o mesmo drama, o mesmo cenário, no mesmo palco estreito, uma humanidade barulhenta, enfatuada de sua grandeza, acreditando-se ser o universo e vivendo na sua prisão como numa imensidão, para logo desaparecer com o planeta, que carregou com o mais profundo desprezo o fardo de seu orgulho.
\end{abstract}

Auguste Blanqui

O declínio da aura acontece no momento em que a fotografia e o cinema surgem no contexto da história da arte, mas as consequências de seu desaparecimento percorrem não só essa área, mas também a história da cultura em geral, resultando no aparecimento da temática do rastro, vestígio ou marca (Spur) como a forma em que está colocada, no mundo contemporâneo, a presença do humano na história. Partindo dessa constatação, Benjamin dedica-se a explorar, implícita ou explicitamente, o declínio da aura e, logo, da experiência (Erfahrung) na modernidade, em consequência do fim da subjetividade ou de uma forma específica de se pensar a história da cultura de um novo modo, no qual a humanidade não está mais no centro dessa criação e os objetos culturais não refletem mais a forma humana em seu interior, como nas narrativas orais, em que a vida humana era o foco e a expressão das histórias contadas, tal como a metáfora do vaso de argila onde fica inscrita a mão de seu feitor, o oleiro. Por consequência, ocorre uma despersonalização daquilo que é cultural, ao passo que a figura do homem torna-se ocultada pelos aparatos técnicos, cada vez mais independentes de quem os fabricou. A realidade desse fato é tão brutal que, em seu ensaio sobre o escritor Kafka, Benjamin afirmará que, no cinema - expressão última do alto grau de nível técnico a que chegou o salto tecnológico -, "o homem não reconhece seu próprio andar e no gramofone não reconhece sua própria voz. Esse fenômeno foi comprovado experimentalmente", e que, "nesse processo, talvez ele encontre fragmentos da própria existência" (BENJAMIN, 2010, 162).

Quando Benjamin, em seu ensaio sobre a Obra de Arte, afirma que a existência única de um objeto artístico cede lugar, graças à técnica de reprodutibilidade que cria a possibilidade da existência serial do objeto, à reprodução do espectador e "atualiza o objeto reproduzido", ela, por consequência, permite que os processos resultem em um "violento abalo da tradição, que constitui o reverso da crise atual", embora, ao mesmo Doutoranda em Educação pela UFSC. Brasileira, residente em Florianópolis. Contato: priscillastuart.di@gmail.com 
tempo, faça também com que ocorra "a renovação da humanidade" (BENJAMIN, 2010, 168-169).

O vestígio, por sua vez, é uma noção que parece indicar a possibilidade de uma nova imagem da humanidade. Para entendê-lo melhor, torna-se necessário pensá-lo junto à aura, já que ambas as noções representam os dois lados de uma mesma moeda, pois quando se está diante de um, o outro está ausente. Desta forma, o vestígio se contrapõe necessariamente à aura, pois enquanto aquele significa a "aparição de uma proximidade, por mais longínquo esteja aquilo que deixou", esta resulta na "aparição de algo longínquo, por mais próximo esteja aquilo que a evoca". Logo, no vestígio, "apoderamo-nos da coisa; na aura, ela se apodera de nós" (BENJAMIN, 490, [M 16a, 4].). Para Benjamin, o aparecimento do rastro está relacionado ao fim da aura, e essa relação começa a se estabelecer com o surgimento da fotografia, e logo, com o cinema, que significou o esfacelamento da experiência aurática1. E, como confirmará o próprio filósofo em uma carta endereçada a Adorno, em 9 de dezembro de 1938, na qual abordava alguns aspectos dessa noção, ele dirá que "o conceito do traço encontrará sua determinação filosófica em oposição ao conceito de aura" (BENJAMIN, 586)2 ${ }^{2}$.

Ao se pensar na polêmica ideia colocada por Benjamin sobre o surgimento do novo homem a partir do "conceito novo e positivo de barbárie" em Experiência $e$ pobreza, é possível dizer que ele cogita um novo tipo de humano que está surgindo e que pode significar algo melhor daquele já posto, justamente quando reflete acerca de temas, tal como as figuras alegóricas conjugadas com a noção de vestígio, com o objetivo de montar uma imagem da modernidade. A famosa frase de Hölderlin em seu poema Patmos se encaixa nesse contexto, funcionando como um possível prognóstico à interpretação benjaminiana da modernidade europeia: "Mas onde há perigo, cresce também o que salva"3.

Quando o traço do corpo humano começa a desaparecer dos objetos históricos, quando o trabalho manual, artesanal, começa a ceder lugar à rede de produção industrial, o que se constata é a uniformidade do trabalho despersonalizado, destituído da marca humana em sua realização. A exemplo dos gestos automatizados encenados por Chaplin em Tempos Modernos, "engolido" pela mecanização dos movimentos

\footnotetext{
1 Quando Benjamin (1987, p. 170) menciona a contemplação de uma colina, alude à aura enquanto experiência: "Observar, em repouso, numa tarde de verão, uma cadeia de montanhas no horizonte, ou um galho, que projeta sua sombra sobre nós, significa respirar a aura dessas montanhas, desse galho".

2 (Tradução livre).

3 "Wo aber Gefahr ist, wächst das Rettende auch". (HÖLDERLIN, 1959, p. 362-363).

Doutoranda em Educação pela UFSC. Brasileira, residente em Florianópolis. Contato: priscillastuart.di@gmail.com
} 
exigida pela padronização dos produtos criados por máquinas, o homem não reconhece mais o valor de seu trabalho frente à nova realidade. Há uma referência direta ao ator inglês quando Benjamin reconhece, na mecanização dos gestos humanos, a mimetização do ritmo fabril: "Na arte dos cômicos é notória uma relação com a economia. Em seus movimentos abruptos, imitam tanto a maquinaria ao assentar seus golpes na matéria, quanto a conjuntura ao assentá-los na mercadoria" (BENJAMIN, 2010, 50). Seu rastro, isto é, sua marca humana, não está mais presente, cedendo lugar à mercadoria, substituída pelo humano. Além disso, é possível afirmar que o humano ganha status de mercadoria, enquanto que esta é compreendida como um objeto constituído de sacralidade.

Quando Benjamin resgata a história do início da Imprensa como uma forma contemporânea de narração em $O$ narrador, percebe-se que o valor da obra de criação humana está condicionado ao mercado. Em seus primórdios, a maior parte das informações dos Reclames era trocada e adquirida durante os cafés, nos intervalos de trabalho - onde ainda se pode divisar algum traço de narrativa oral - na chamada "imprensa do bulevar": "a atividade dos cafés treinou os redatores no ritmo do serviço informativo antes mesmo que sua maquinaria estivesse desenvolvida. Quando, por volta do fim do Segundo Império, o telégrafo elétrico entrou em uso, o bulevar perdera seu monopólio" (BENJAMIN, 2010, 24).

O surgimento do vestígio como parte dessa história cultural envolvendo a imprensa, os gêneros literários e os novos aparatos técnicos, incluindo o telégrafo, será tratado por Benjamin no ensaio sobre a Paris do Segundo Império, a partir da multidão ou da massa. Cumpre notar que há uma diferença entre a massa, identificada como uma instância que antecede a consciência de classe e que Marx chamará de Lumpemproletariado, e a multidão, um modo mais poético de se pensar os indivíduos em grupo, momento em que as pessoas se tornam mais proletarizadas. Mas essa divisão será levantada quando, ao final deste texto, se refletirá acerca de que tipo de subjetividade se forma em um momento histórico em que a experiência está em declínio e a capacidade de elaboração da memória torna-se uma vivência (Erlebnis) destituída de seu elemento épico. Portanto, o vestígio é uma espécie de símbolo representativo da condição moderna do homem destituído de sua história, em um momento em que o 
produto de seu trabalho (e por extensão, ele próprio como sujeito) perde seu valor devido às transformações do mercado na era do capital ${ }^{4}$.

\section{0 humano como mercadoria}

O esvaziamento da ideia de humano começa no momento em que tudo se torna passível de troca e objeto de consumo, sendo que o ápice desse momento ocorre quando o próprio humano se reifica. Esse momento de reificação - expressão pouco tratada por Marx, mas desenvolvida largamente por Lukács - acontece desde o momento em que a gênese de todo o processo de trabalho manual até o industrial, "passando pela cooperação e pela manufatura, até a indústria mecânica", converge para uma racionalidade continuamente crescente, uma eliminação cada vez maior das propriedades qualitativas, humanas e individuais do trabalhador" (LUKÁCS, 2003, 201). Por consequência, a ideia de humanidade se esvazia, desaparecendo e sendo substituída pelas simples e desagregadoras relações de consumo.

Os valores do mercado que ditam o modo como se estabelecem essas relações de consumo são temas explorados a partir da discussão acerca da mercadoria levantada por Marx e retomada por Benjamin na discussão sobre a modernidade. Para ele, que retoma a discussão iniciada pelo autor de $O$ Capital, a mercadoria está completamente destituída de seu valor de uso, mesmo quando exposta nas vitrines. Seu uso é o que menos importa frente ao entorpecimento do fetiche provocado nos indivíduos. Pensada na perspectiva de seu valor de uso, na mercadoria, "não há nada de misterioso, seja do ponto de vista de que ela satisfaz necessidades humanas por meio de suas propriedades, seja do ponto de vista de que ela só recebe essas propriedades como produto do trabalho humano" (MARX, 2017, 146). No momento em que ela é fabricada e uniformizada pela indústria, o trabalhador que a produz já está alienado de seu significado histórico. A mercadoria, desprovida de seu valor de uso, exerce poder nas sociedades industrializadas graças à sua forma, que representa "aos homens os caracteres sociais de seu próprio trabalho como caracteres objetivos dos próprios produtos do trabalho". Ou seja, segundo Marx, é necessário entrar na "região nebulosa do mundo religioso" para entender a sutileza do fascínio que as mercadorias exercem no aparato cognitivo dos homens. "Os produtos do cérebro humano parecem

\footnotetext{
${ }^{4}$ Expressão usada por Hobsbawn.
} 
dotados de vida própria, como figuras independentes que travam relação umas com as outras e com os homens. Assim se apresentam, no mundo das mercadorias, os produtos da mão humana". Na sequência, completa Marx: "A isso eu chamo de fetichismo, que se cola aos produtos do trabalho tão logo eles são produzidos como mercadorias e que, por isso, é inseparável da produção de mercadorias" (MARX, 2017, 147-148.).

Definição similar pode ser encontrada em Benjamin, para quem a alegoria é o elemento novo na interpretação sobre a condição do homem transformado em mercadoria junto ao esvaziamento do significado dos objetos e seus usos em função do vertiginoso efeito do fetiche causado na multidão. Por uma via poética, Benjamin acredita que é possível estabelecer alguma ruptura com a alienação do indivíduo em meio ao status quo positivista vigente. E para que isso aconteça, somente com a constante proletarização do trabalhador (que no pensamento de Benjamin poderia ser pensado como o "despertar") seria possível atingir uma parte da ação que tem como função interpretar a realidade. A outra dimensão do método benjaminiano, na interpretação da modernidade, é a categoria do sonho ${ }^{5}$, que representa os conteúdos e as imagens que expressam o inconsciente coletivo.

Dentro dessas esferas que indicam um antídoto contra o capitalismo que significou, em seu surgimento, "um fenômeno natural com o qual um novo sono, repleto de sonhos recaiu sobre a Europa" (BENJAMIN, 2009, 436 [K, 1aㅗ, 8]), para o filósofo, "o spleen é o sentimento que corresponde à catástrofe em permanência" (BENJAMIN, p. 394 [j, 66a, 5]), resultado da modernidade capitalista. Contrariamente a isso, somente com a destruição alegórica - que insere uma ruptura com o valor mercadológico das coisas - seria possível escapar da contingência do real. Não é à toa que ele afirma que o poema La destruction 6 é o que melhor simboliza a "intenção alegórica" baudelairiana (BENJAMIN, 2009, 394 [j, 68, 1].).

\footnotetext{
${ }^{5}$ Grosso modo, tanto o despertar quanto o sonho em Benjamin aparecem em diferentes momentos de sua obra, mas no contexto das Passagens, ou seja, de sua leitura da modernidade, ele vai afirmar que o século XIX tem um caráter onírico (que se expressa sobretudo na moda, na arquitetura em geral e nos interiores burgueses), daí a dificuldade de se interpretar essa época. Diante disso, ao operar com o método do despertar/sonho para interpretar o presente, ocorre a rememoração do passado através daquele. Em Sobre o conceito de história, o momento do despertar seria o mesmo do Jetztzeit. O sonho, nesse caso - que é o outro lado do método e que precede aquele - é a própria matéria da recordação realizada pelo despertar (In. WEIDMANN, p. 305-337).

${ }^{6}$ Sans cesse à mes côtés s'agite le Démon;/ll nage autour de moi comme un air impalpable;/Je l'avale et les sens qui brûle mon poumon/Et l'emplit d'un désir éternel et coupable (...)

(...) Et jette dans mes yeux pleins de confusion/ Des vêtements souillés, des blessures ouvertes,/ Et l'appareil sanglant de la Destruction!" (BAUDELAIRE, 2015, p. 346).
} 
Voltando, então, à realidade imposta pela modernidade desenfreada que significou um prejuízo à ideia de humanidade, o tratamento do homem na sociedade moderna transformado em mercadoria sinaliza, provavelmente, o motivo de seu desaparecimento sobre o planeta e sua sobrevivência como vestígio. A imagem do homem no mercado de trabalho, engolido em sua individualidade, evidencia apenas a força de trabalho que deve ser produtiva e dar rendimento à indústria e à classe que o explora. Na esteira dessa discussão, em Boêmia, parte de seu inacabado ensaio sobre a Paris do Segundo Império, Benjamin discorre sobre a forma proletarizada do indivíduo exilado de si mesmo e de seus interesses durante seu trabalho nas fábricas. A forma como o trabalhador foge da condição de escravo do processo produtivo, em suma, da condição de ver-se convertido em mercadoria, é alcançada por meio da educação de sua condição social, politizando-se, agindo como conspirador contrário à ordem vigente.

Em Boêmia, essa condição é exemplificada na figura dos conspiradores de ocasião, que procuram uma brecha em seu tempo e "que só enxergam a conspiração a par de suas outras ocupações e que, só com a ordem do chefe, frequentavam os encontros e ficavam de prontidão para comparecer ao ponto de reunião" (BENJAMIN, 2010, 9). Essa ação ainda é uma forma política de combate, mas vista sob uma ótica mais abstrata, é uma forma de lutar pela ideia de indivíduo em geral, que quer garantir a conservação de seus interesses na garantia da própria sobrevivência, reconhecendo-se como um sujeito respeitado em sua completude, na sua esfera de trabalho.

Ainda em Boêmia, Benjamin mostra como, diante da crescente modernização da cidade, ocorreu o afastamento das classes populares e de condição maior de vulnerabilidade, do centro de Paris à sua periferia. Por consequência, os conspiradores são solapados, dando prosseguimento à cultura dominante que assume a dianteira da história em ritmo acelerado, momento em que surgem os romances de folhetins e a crescente procura dessa literatura pequeno-burguesa, que revela a crescente desvalorização do literato.

Diante de um mercado que exigia uma produção exacerbada dos escritores, muitos deles, segundo boatos da época relatados por Benjamin, eram contratados pelos próprios escritores, incluindo o caso de Dumas (BENJAMIN, 2010, 26), que os utilizavam como uma espécie de ghost writers. Antes disso, o ritmo da literatura estava à mercê da imprensa de bulevar, mas com o aumento dos jornais da época devido à invenção do telégrafo, esse ritmo frenético passou a influenciar a produção literária de então. 
Nesse momento, a figura da prostituta passou a representar bem o papel do literato. O flâneur de Baudelaire, que representa todas as alegorias e uma espécie de jogo social da modernidade, se converte ou se transveste de prostituta durante todo o ensaio, pois está à mercê daqueles que estão dispostos a pagar mais. Frente a isso, percebe-se uma dialética da relação entre o trabalho e a prostituição, pois esta "pode ter a pretensão de considerar-se 'trabalho', a partir do momento em que o trabalho se torna prostituição" (BENJAMIN, 2009, 393 [j, 67, 5]). Tanto sua obra literária está à venda quanto ele próprio como sujeito condicionado às regras do mercado cultural.

Deste modo, a condição do literato analisada por Benjamin é também a do humano transformado em mercadoria: "Baudelaire sabia como se situava, em verdade, o literato: como flâneur ele se dirige à feira; pensa que é para olhar, mas na verdade, já é para procurar um comprador" (BENJAMIN, 2010, 30). Logo, a alegoria é o modo de se situar um passo para fora do entorno capitalista, que transforma todo indivíduo em massa, e é por isso que Benjamin afirma que ela é a "armadura da modernidade" (BENJAMIN, 2010, p. 172) e a forma de se proteger dos constantes choques provocados pelo conjunto de aspectos formado pelo imenso turbilhão que transforma ainda hoje a vida do indivíduo continuamente.

\section{Os rejeitos humanos, o trapeiro}

O trapeiro é a figura mais provocadora da miséria humana.

Walter Benjamin

Essa transformação do indivíduo pode ser bem ilustrada pela figura do trapeiro, daquele que está situado aquém da condição digna de trabalho e para quem a rua e a casa são dimensões tênues, ou seja, seu habitat é constituído por aquilo que consegue lucrar em sua condição de vulnerabilidade, de modo que as fronteiras entre o público e o privado estão continuamente diluídas. É a forma de sobrevivência de um trabalho artesanal inaugurado nas metrópoles e que ainda permanece como expressão daqueles que lutam para não serem reduzidos à própria matéria do que recolhem.

Ser trapeiro é uma condição que foi surgindo natural e espontaneamente em um lugar histórico novo, a urbe, espaço transformado em depósito dos restos espalhados pelas ruas e calçadas e descartados pela burguesia. Enquanto ela dorme, o trapeiro trabalha para fazer desaparecer a sujeira de uma classe destituída da consciência de que as coisas têm um sentido que ultrapassa os limites da utilidade. Por isso, Benjamin 
afirmará que a alienação decorrente da apropriação do objeto dentro das fronteiras do "ter" eliminou o caráter ou os "sentidos físicos e espirituais" dos objetos materiais (BENJAMIN, 2009, 243 [H, 3a, 2]). No entanto, a particularidade desse trabalhador outsider é que seu gesto de recolher os objetos abandonados the permite se apropriar de um aspecto do objeto que a burguesia não conhece, pois se encontra inebriada pelo consumo da lógica capitalista. $O$ trapeiro utiliza-se desses objetos, inserindo-os em um contexto poético, pois ordena sua coleção de maneira idiossincrática, familiar, resgatando seu valor sacralizado e transformando-os, por sua vez, em artigos afetivos.

Seu gesto, portanto, é uma forma de denúncia da relação exclusivamente utilitarista desenvolvida pela sociedade capitalista em sua relação com os objetos, estabelecendo, assim, uma nova forma de experiência histórica. Essa experiência com o mundo material, no presente atual, indica que as coisas estão fragmentadas, algo que faz pensar na ideia de ruína dos românticos. O mundo, tal como é pensado hoje, é apenas um vestígio do passado, e a reconstrução dessa totalidade só é possível por um trabalho de rememoração e de recriação de significados daquilo que resta hoje.

Quando se faz uso da palavra gesto, a palavra deve ser pensada também em seu sentido literal, pois se as mercadorias consumidas e descartadas são o fruto de um fetiche social, esse fetiche é causado pela visão, pelo olhar embriagador das massas que percorrem as vitrines, repletas de encantos extrassensoriais. O gesto do trapeiro, por sua vez, remete a um significado que desloca a atenção da visão para a percepção tátil: cheio de sugestões e significados novos, a percepção tátil alude à capacidade memorativa, transportando o sujeito a reminiscências sutis da história humana.

Como o próprio Benjamin afirmará, tocar nos objetos, gesto de um trapeiro - que é um "verdadeiro colecionador" -, "retira os objetos de suas relações funcionais", de modo que ele se torna um "mago", pois forma com "cada uma de suas possessões uma completa enciclopédia mágica, uma ordem no mundo, cujo esboço é o destino de seu objeto" (BENJAMIN, 2009, 241, [H 2, 7; H 2a, 1]).

Assim como o poeta que faz poesia dos detalhes, como se cada coisa fosse uma espécie de deus das coisas pequenas, o trapeiro sugere que a própria história humana está fadada a ser contada por esses pequenos fragmentos espalhados pelas ruas das metrópoles, sendo que é justamente nelas que, muitas vezes, "vê-se um trapeiro cambaleante, a fronte inquieta/Rente às paredes a esgueirar-se como um poeta, /E, alheio aos guardas e alcaguetes mais abjetos, /Abrir seu coração em gloriosos projetos" (BAUDELAIRE, 2015, 335). 
Além de recolher os destroços e objetos rejeitados, isentos de história, memória, esvaziados de significados afetivos, a condição do trapeiro sugere a de alguém que se tornou um vestígio do que é ser humano: categoria esquecida, invisível, que vive à margem da ideia de classe, sua existência parece ser uma espécie de improviso do trabalho: "maior número de trapeiros surgiu nas cidades desde que, graças aos novos métodos industriais, os rejeitos ganharam certo valor. Trabalhavam para intermediários e representavam uma espécie de indústria caseira situada na rua" (BENJAMIN, 2010, 16). Como forma ou símbolo do esvaziamento de valor em si mesmo do humano, o trapeiro é o primeiro vestígio da miséria social a que foi e está submetida a humanidade no surgimento das cidades industrializadas, como algo nunca antes visto: "o trapeiro fascinava a sua época. Encantados, os olhares dos primeiros investigadores do pauperismo nele se fixaram com a pergunta muda: 'Onde seria alcançado o limite da miséria humana?"” (BENJAMIN, 2010, 16).

A sobrevivência do flâneur-trapeiro depende da experiência que realiza a partir dos objetos que encontra, do cotidiano da cidade ou das manobras que percorre para conseguir alcançar um caminho mais transitável no labirinto da metrópole esquecida dos que ficaram à margem. O que tudo isso indica é que o flâneur, de trapeiro, transforma-se na alegoria do detetive para tentar transpassar os limites intransponíveis dos espaços públicos que, para o trapeiro, se confundem com a esfera privada, já que seu destino é tentar manobrar os constantes choques a que está submetido diariamente. Afinal, recolher os restos ou os vestígios perdidos ou ignorados nas ruas também cabe ao detetive.

\section{A alegoria do detetive}

"Quem não assinou, quem não deixou retrato Quem não esteve presente, quem nada falou Como poderão apanhá-lo! Apague as pegadas" Brecht

Benjamin foi um grande leitor de romances policiais. Isso se constata pelas suas referências ao gênero no aforismo Romances policiais, nas viagens, parte de sua prosa poética Imagens de pensamento. E é com esse gênero que Baudelaire, segundo o filósofo, fará sua poesia do apache, representada pelas Flores do Mal como leitura das experiências de choque da vida moderna. 
O romance policial, enquanto inspirador da poesia de Baudelaire, é um gênero importante para a compreensão dos elementos que desvendariam todas as particularidades da cidade grande e, quiçá, da modernidade. Como representação desse novo espaço, qual será o lugar do indivíduo em seu interior e por que o detetive se torna uma alegoria importante? A resposta só pode ser a seguinte: "o conteúdo social primitivo do romance policial é a supressão dos vestígios do indivíduo na multidão da cidade grande" (BENJAMIN, 2010, 41). A cidade como um labirinto, segundo Benjamin, "penetrou na carne e no sangue do flâneur" (BENJAMIN, 2010, 178), e é assim, certamente, que sua transfiguração em detetive se tornou necessária para ele conseguir se movimentar em meio aos perigos dessa nova configuração histórica da modernidade. Desta forma, "o amante da vida universal entra, assim, na multidão como num imenso reservatório de eletricidade". Esse indivíduo tão peculiar, que tem a capacidade de observar no limiar (pois vive na ociosidade, fora dos limites impostos pelo capitalismo emergente), é também pensado como "um espelho tão grande quanto essa multidão; a um caleidoscópio dotado de consciência que, a cada um de seus movimentos, representa a vida múltipla e a graça cambiante de todos os elementos da vida". Sua personalidade transforma-se em "um eu insaciável do não-eu, que, a cada instante, o traduz e o exprime em imagens mais vivas que a própria vida, sempre instável e fugidia" (BAUDELAIRE, 2010, 30-31).

O flâneur transforma-se em detetive porque, além de contemplar a paisagem urbana, procura também, de acordo com a forma como se desloca e se movimenta na cidade, sinalizar uma maneira particular de viver no espaço urbano. Sua própria alegoria, dessa forma, segundo Benjamin, "prenuncia a do detetive". Por isso, ele "devia procurar uma legitimação social para seu comportamento. Convinha-lhe perfeitamente ver sua indolência apresentada como aparência, por detrás da qual se esconde de fato a firme atenção de um observador seguindo implacavelmente o criminoso de que nada suspeita" (BENJAMIN, 2009, 485 [M, 13a, 2]). Portanto, se o "flâneur se torna sem querer detetive, socialmente a transformação lhe assenta muito bem, pois justifica sua ociosidade. Sua indolência é apenas aparente. Nela se esconde a vigilância de um observador que não perde de vista o malfeitor" (BENJAMIN, 2010, 38).

Ao buscar sua fonte em Poe, como fez Baudelaire, Benjamin mostra como a realidade moldou o gênero literário e vice-versa. Ao pensar a história da cultura fora desses limites textuais de gênero, ele ressalta o valor da obra ficcional de Poe como leitura de um tempo passado que ecoa no presente, como relata na carta anteriormente 
citada: "meu primeiro ato depois do meu retorno foi buscar uma passagem importante em Poe para minha construção da história de detetive como derivada da obliteração ou fixação dos traços do indivíduo na multidão da grande cidade" (BENJAMIN, 2009, 586).

Logo, a busca de evidências e vestígios constitui-se como a tarefa do detetive, exemplificada no personagem Dupin, figura simbólica nos contos de Poe. Mas sua caçada ao criminoso, como no Assassinato de Marie Roget, é infrutífera, uma vez que, na multidão das ruas, predomina um ritmo tão frenético, efêmero, que não é possível encontrar o fugitivo, tal a velocidade com que as coisas se dispersam. Desta forma, a esfera de ação do detetive é deslocada, pois não há um espaço fixo possível de investigação. A assassinada Marie pode ter seguido tanto o mesmo caminho regular quanto se desviado de sua rota costumeira, já que o detetive, nesse conto de Poe, "não trabalha com base nas aparências, nas observações pessoais, mas sim nas reportagens da imprensa diária. A análise crítica das reportagens fornece os alicerces da narrativa" (BENJAMIN, 2010, 41) do escritor.

O detetive de Poe é descrito pormenorizadamente no conto que antecede 0 citado acima, dando sequência a ele, a saber, Os crimes da rua morgue. Dupin, neste conto, é descrito como alguém que aprecia o anoitecer e a lugubridade das ruas, alguém que, quando a multidão está mais esvaecida, busca "entre as luzes e as sombras fantásticas da populosa cidade, as inumeráveis excitações mentais que a observação tranquila pode proporcionar". Dotado de "uma peculiar capacidade analítica", o detetive é sagaz em recolher - semelhante ao trapeiro que o faz com as sucatas e tudo aquilo que é descartado pelos transeuntes - o material deixado pelo criminoso e refazer, motivado pela criatividade e capacidade inventiva, a ordem dos acontecimentos do crime (POE, $\mathrm{s} / \mathrm{d}, 103)$.

Enquanto o narrador-amigo passeia pela rua do Palais Royal com Dupin, este adivinha o pensamento do amigo somente pelos elementos que se deparam ao longo do caminho percorrido, que inclui o "Chantilly, Órion, Doutor Nichols, Epicuro, estereotomia, as pedras da rua, o vendedor de frutas" (POE, s/d, 104-107), o que se reforça quando diz que: "Na verdade, esse rapaz é muito pequeno e estaria melhor no Théâtre des Variétés". Conforme se explica no conto, o detetive percorre, pelo pensamento, todos os lugares, os objetos e as pessoas que encontra pelo caminho, chegando ao mesmo resultado do pensamento de seu amigo.

Deste modo, esta é a noção de vestígio presente nos contos policiais, que forma parte da realidade do que é a cidade grande. E "com isso se compreende como o 
romance policial, a despeito de seu sóbrio calculismo, também colabora na fantasmagoria da vida parisiense" (BENJAMIN, 2010, 39), pois as coisas estão dispersas e o perigo iminente nem sempre é percebido. A cidade agora é o lugar onde prevalece um sentimento de insegurança, de constantes choques, afinal, segundo o próprio Baudelaire citado por Benjamin, "o que são os perigos da floresta e da pradaria comparados com os choques e conflitos diários do mundo civilizado?" (BAUDELAIRE apud BENJAMIN, 2010, 37). Neste sentido, a modernidade é uma época sui generis para os conflitos humanos, pois se está diante do desaparecimento do indivíduo sobre a Terra.

Nesse caso particular, a capital francesa, como palco da história moderna, com sua urbanização realizada pelo Barão de Haussmann, representou uma forma de combater os insurgentes e as barricadas, mas também serviu de modelo e inspiração para outras cidades no mundo. Construída de maneira simétrica, espelhar, proporciona a sensação de sonho, de devaneio, de imersão, que foi percebida pelos artistas frequentadores do Clube dos Hashischins, por exemplo. Uma cidade, portanto, que foi o lugar para experiências com alucinógenos, da exaltação espontânea que a contemplação da cidade causava tanto no século XIX quanto atualmente.

Ciente disso, o próprio Benjamin relatou suas experiências com o haxixe em Imagens do pensamento. Contudo, é o visual especular de Paris, a cidade no espelho propícia, aliás, ao desaparecimento de vestígios - que merece destaque:

A cidade se espelha em milhares de olhos, em milhares de objetivas. Pois não apenas o céu e a atmosfera, nem apenas os anúncios luminosos nos bulevares noturnos fizeram de Paris a Ville Lumiére. Paris é a cidade dos espelhos: o espelhado do asfalto de suas ruas. Diante de cada bistrô recantos envidraçados (...) Espelhos são o elemento intelectual desta cidade, seu brasão, no qual se inscrevem os emblemas de todas as escolas poéticas... Sena... é o grande e sempre desperto espelho de Paris. Diariamente a cidade lança neste rio suas sólidas construções e seus sonhos de nuvens como se fossem imagens. Magnânimo, ele aceita as oferendas e, em sinal de agradecimento, as fragmenta em mil pedaços (BENJAMIN, 2009, p. 197-198).

Tanto Baudelaire quanto Benjamin utilizaram-se dessas substâncias para experimentar novas experiências, misturando as próprias sensações com o corpus da metrópole. E em meio a essa atordoante capital da modernidade europeia, o detetive busca os vestígios daquilo que escapou.

A alegoria do detetive representa, portanto, a cidade em sua nova configuração social, as funções exercidas por cada instância da nova urbe. E é por isso que o 
romance policial, para Benjamin, será o responsável por revelar as características da cidade grande e, em última instância, da modernidade.

\section{0 vestígio: entre o público e o privado}

A questão do vestígio na Paris do Segundo Império apresenta um desdobramento muito amplo, pois Benjamin tenta resgatar os vestígios de uma microhistória quando destaca, entre a boêmia parisiense, os sujeitos e as figuras esquecidas pela história oficial. Neste caso, são os vestígios da classe operária, proletária. Mas o vestígio que interessa em Benjamin, mais especificamente, é o do desaparecimento do homem sobre a Terra, já que, em um mundo uniformizado, onde as pessoas e suas casas são marcadas por números e as individualidades solapadas pela padronização, "a burguesia se empenha em buscar uma compensação pelo desaparecimento de vestígios da vida privada na cidade grande. Busca-a entre suas quatro paredes".

Logo, é por isso que Benjamin converte o tempo em espaço na leitura da modernidade burguesa, pois, para uma classe, representada pela reforma urbana de Paris, quando a modernidade e o progresso esmagaram bairros proletários repletos de barricadas e a história anterior para dar lugar ao novo, nada mais resta que, como "questão de honra não deixar se perder nos séculos, se não o rastro de seus dias na Terra, ao menos o dos seus artigos de consumo e acessórios". E isso se explica porque a dissolução entre o privado e o público passa a ser a norma desse novo espaço moderno, onde o indivíduo burguês não mais se realiza em seus ambientes particulares. Por isso, "tira o molde de uma multidão de objetos; procura capas e estojos para chinelos e relógios de bolso, para termômetros e porta-ovos, para talheres e guardachuvas. Dá preferência a coberturas de veludo e de pelúcia, que guardam a impressão de todo contato" (BENJAMIN, 2010, 43). Comparando os esforços da burguesia para preservar a existência humana na Terra a uma fauna extinta, o indivíduo moderno trata o espaço privado como "uma espécie de cápsula", "preservando assim, os seus vestígios". Consequentemente, o processo de normatização que acompanha a história moderna humana, mais precisamente desde a Revolução Francesa, é irreversível, e tal medida não compensa, mas aprofunda "a perda de vestígios que acompanha o desaparecimento do ser humano nas massas das cidades grandes" (BENJAMIN, 2010, 44). 
Como o próprio Benjamin afirma, o "conforto isola" na mesma medida que "aproxima da mecanização os seus beneficiários" (BENJAMIN, 2010, 124). Em Habitar sem vestígios, parte do conjunto de aforismos de Imagens do pensamento, argumenta que "a impressão mais forte, em meio de todo o 'aconchego' que talvez irradie, é: - Aqui nada tens a procurar. - $E$ isto porque não há canto no qual o morador já não tenha deixado seu vestígio". Fruto do receio de que seus vestígios desapareçam da Terra, "o interior [das casas burguesas] obriga seus moradores a adquirir a quantidade maior possível de hábitos" (BENJAMIN, 2009, 266).

O indivíduo sobrevive como vestígio em seus interiores, e assim como no espaço urbano da cidade, ele desaparece como massa ou multidão. Qualquer indivíduo que já perambulou por alguma urbe sente a experiência que Benjamin descreve sobre a multidão. As pessoas, caminhando cada uma à sua maneira, bitoladas em suas próprias ocupações e pensamentos, indiferentes ao movimento vertiginoso das ruas e avenidas, estão embriagadas pelos constantes ruídos e odores, em suma, choques simultâneos que provocam o turbilhão dos acontecimentos.

Desta forma, habituados, cada um por si, ao ritmo citadino, como se fizessem parte de uma maquinaria industrial, andando conforme movimentos repetidos e contínuos, os indivíduos perdem a capacidade de se apropriarem da própria experiência enquanto sujeitos de si mesmos, de modo que lhes resta apenas a vivência de realidades impositivas e sucessivas, superadas a cada dia por novos e mais profundos choques.

Em seu célebre ensaio sobre a Psicologia das massas e análise do eu, Freud mostra a sobrevivência de apenas um traço ou vestígio do indivíduo frente à desintegração da personalidade humana absorvida às massas comuns. E essa tendência à dissolução do eu à identificação como massa é parte de um vestígio, ou algo mais primitivo, como um instinto gregário, uma "tendência de todos os seres vivos, procedentes da libido, a juntar-se em unidades cada vez mais abrangentes". Como o psicanalista austríaco é uma referência importante para Benjamin, conforme se constata em Sobre alguns temas em Baudelaire, é importante salientar suas referências às massas como um lugar destituído de experiência humana, como um espaço, segundo Freud, de "enfraquecimento da aptidão intelectual", entre outras coisas, incluindo a "tendência a ultrapassar todas as barreiras na expressão de sentimentos e a descarregá-los inteiramente na ação" (FREUD, 2011, 77-78). 
Com a massa, portanto, advém a possibilidade de anular o indivíduo em seu próprio meio, fazendo-lhe restar apenas um vestígio de seu próprio eu, o indivíduo, o qual, na tentativa de resgatar a supressão de sua humanidade, transforma seus ambientes domésticos e privados em espaços onde possa deixar sua marca ou vestígio. As inúmeras vitrines revestidas de vidro, que não deixam os traços de quem passou, são uma indicação do desaparecimento do humano da Terra, ou então, o sintoma de uma nova forma de subjetividade nascente, a do homem novo. Em outras palavras, ocorre uma "multiplicação dos rastros devido ao aparato administrativo moderno" (BENJAMIN, 2009, 258 [l, 6a, 4]), indicando que "talvez exista uma correlação entre a diminuição do espaço habitável e a crescente decoração do intérieur' (BENJAMIN, 2009, 258 [I, 6, 5]).

O homem está ciente de que seu lugar na história será esquecido e que sua presença no planeta se encontra potencialmente em extinção. As decorações de ambiente sofisticadas e carregadas de pessoalidade de seu dono são sintomas da decadência humana, que anunciam o seu fim, uma vez que "os estojos, as capas protetoras, as caixinhas - com os quais se recobriam os pertences domésticos burgueses do século anterior - eram outros tantos dispositivos para registrar e conservar rastros" (BENJAMIN, 2009, $261[1,7,6])$.

\section{5 À guisa de conclusão: O homem novo}

A salvação se apega à pequena fissura na catástrofe contínua.

Walter Benjamin

A noção de um novo homem que renasce das cinzas, assim como a fábula da ave fênix, aparece no conhecido ensaio de Benjamin, Experiência e pobreza. Nele, o filósofo afirma que "um conceito novo e positivo de barbárie" para o qual a humanidade se encaminha, surge nessa transição que dá lugar ao novo, à arquitetura de vidro, às inovações tecnológicas, etc. Portanto, esse conceito sugere que a barbárie em si é o estado atual da cultura, e que para vislumbrar uma nova realidade, esta deve ocorrer a partir dos restos e dos vestígios da destruição do passado.

Desta forma, somente a partir da ruína o homem conseguirá elaborar o presente em busca de seu futuro, pois, qual é o destino, isto é, o que deve esperar uma humanidade destituída da capacidade de elaborar os conteúdos de sua experiência, uma vez que sua memória foi e é constantemente atravessada pelos choques crescentes da realidade da metrópole moderna? Afinal, a condição do homem na 
modernidade é estar destituído da possibilidade de realizar experiências, uma experiência que se traduz em vivências de choque, situação em que o homem só se relaciona com a realidade através de uma mediação feita pelos novos aparatos técnicos.

Benjamin acredita que há um conceito positivo de barbárie porque, para ele, a salvação (Rettung) - categoria muito importante em seu pensamento ${ }^{7}$ - encontra-se nesses "entre-lugares" ou limiares da crescente catástrofe moderna, como indica a epígrafe desta seção. Para isso, é preciso olhar para os homens de exceção como Descartes ou Einstein e construir um futuro "a partir de uma tábula rasa”. Ele sugere que é preciso olhar a partir de uma outra perspectiva para o passado em direção ao futuro, tal como fizeram artistas como Adolf Loos e Paul Klee, que recusaram a "imagem do homem tradicional, solene, nobre, adornado com todas as oferendas do passado, para dirigir-se ao contemporâneo nu, deitado como um recém-nascido nas fraldas sujas de nossa época”. Paul Scheerbart, segundo Benjamin, fez isso melhor do que qualquer outro escritor, pois, dentre outras coisas, conseguiu apontar uma dimensão diferente tanto para o homem quanto para a pobreza da experiência, já que a nova "cultura de vidro" tende a mudar completamente os homens (BENJAMIN, 2010, 118), abrindo um arsenal de possibilidades sem precedentes.

Essa nova imagem, descrita nos personagens de Scheebart, profetiza a realidade à qual se encaminha: só há vestígios, sendo que os personagens de Scheebart negam "qualquer semelhança com o humano, princípio fundamental do humanismo" (BENJAMIN, 2010, 118). Os ambientes burgueses são o maior exemplo de como os objetos se tornaram "opacos" para o homem, não o refletindo em toda sua humanidade.

A nova "cultura de vidro" e o aço da Bauhaus "mudar[ão] completamente os homens". E essa é uma realidade esperada por eles, pois a necessidade é a de se livrar de toda a experiência, pois os homens "aspiram a um mundo em que possam ostentar tão pura e claramente sua pobreza externa e interna". Os valores estão extintos, as coisas tornam-se despojadas de significados, o que vale é o instante e o presente esvaziado de passado. A necessidade ou os objetivos do indivíduo na vida atual estão condicionados "apenas como o mais remoto ponto de fuga numa interminável perspectiva de meios". Por consequência, "surge uma existência que se basta a si mesma, em cada episódio, do modo mais simples e mais cômodo, e na qual um

7 Cf. KAULEN, H. Salvación. In: OPITZ, M.; WIZISLA, E. Conceptos de Walter Benjamin. Trad. María Belforte y Miguel Vedda. Buenos Aires: Las Cuarenta, 2014, p. 1057-1122. 
automóvel não pesa mais que um chapéu de palha, e uma fruta na árvore se arredonda como a gôndola de um balão" (BENJAMIN, 2010, 118-119).

A barbárie positiva parece fazer alusão ao que ainda resta do homem despossuído de seu passado e da capacidade de reconhecer, nos patrimônios históricos e culturais, sua própria vida, em suma, uma história coletiva que possa reverberar em sua história pessoal, em sua biografia. Logo, o que resta do homem destituído da capacidade de experienciar e compartilhar o produto de suas experiências?

Para Benjamin, é a capacidade de sonhar ou a habilidade de sua imaginação que faz o homem ser capaz de seguir em frente, de construir novos rumos e horizontes. Ao se referir a uma espécie de cansaço histórico da qual o homem europeu sofre, exaurido de "devorar" sua extensa bagagem cultural, o homem contemporâneo deseja livrar-se de toda e qualquer experiência, pois sente o peso da história coletiva sobre os ombros, incapacitando-o de um olhar livre para novas criações. Por isso, acreditando na capacidade do homem novo que não vincula mais seu passado com seu presente, ele se sente livre para imaginar que: "ao cansaço segue-se o sonho, e não é raro que o sonho compense a tristeza e o desânimo do dia, realizando a existência inteiramente simples e absolutamente grandiosa que não pode ser realizada durante o dia, por falta de forças" (BENJAMIN, 2010, 118).

Como dito acima, as coisas não têm mais valor em si mesmas. Sua utilidade se reduz ao seu efeito no momento atual, efêmero. Por isso, para Benjamin, o que se percebe nesse "conceito novo e positivo de barbárie" é que "a humanidade se prepara, se necessário, para sobreviver à cultura", e assim, direcionar-se ao novo. "A existência do camundongo Mickey é um desses sonhos do homem contemporâneo", ele exemplifica, ao atestar que o homem, graças à capacidade da imaginação, pode olhar para o futuro (BENJAMIN, 2010, 116, 118, 119).

No personagem de $O$ foguista, de Kafka, talvez haja uma referência a essa noção de novo homem. No conto, que fora publicado como o capítulo inicial de seu primeiro romance, O desaparecido ou Amerika (Der Verschollene), narra-se a história de um jovem chamado Karl Rossmann, que sai de sua terra natal, na Alemanha, em busca de novas perspectivas na Amerika, um país novo que simboliza a possibilidade de começar uma vida nova sem o peso da história e de uma tradição que a anteceda. Como Benjamin afirma: "a importância de Amerika na obra de Kafka é demonstrada pelo próprio nome do herói. Enquanto nos primeiros romances o autor se designava apenas, 
em surdina, por uma inicial, nesse livro ele nasce de novo, no novo mundo, com seu nome completo" (BENJAMIN, 2010, 144-145).

O personagem viaja de navio até Nova York para recomeçar sua vida após um incidente em seu país natal. É importante observar que, durante essa viagem até a cidade prometida, Karl carrega uma mala com alguns pertences pessoais que simbolizam seu passado e sua história na Alemanha, país que pertence a um continente carregado de tradições, lembranças e memórias. Um fato curioso é que, enquanto acontece essa viagem, a mala não sai de perto de Karl, sobretudo pelo medo de ser furtado, pois nem mesmo durante as madrugadas ele a perde de vista. Contudo, quando o navio aporta em terra, por um descuido fortuito, ele deixa sua mala aos cuidados de um conhecido, já que precisava pegar seu guarda-chuva esquecido em uma cabine. Daí por diante, a história se desenrola, pois Karl encontra o foguista do navio, chamado Franz Butterbaum, ao passo que, enredado por conversas e outras situações labirínticas - próprias das histórias kafkianas -, sua mala se perde. Ao final do conto, ele desembarca do navio com seu tio rumo à cidade, sem se importar por ter deixado suas roupas, seu salame veronês e outros objetos trazidos da Alemanha, como a foto de seus pais, por exemplo. Enfim, coisas que significam seu elo com sua terra, uma parte dela sendo levada à cidade nova.

Dentre as inúmeras interpretações possíveis para essa história, assim como acontecem com as fábulas, em que a moral da história não está previamente dada, é possível interpretar esse esquecimento despretensioso como a metáfora de um indivíduo (nesse caso, um jovem de 16 anos) sem passado, que olha para frente, rumo a um futuro sem uma tradição a "carregar" - representada pelos objetos pessoais presentes na mala. Um abandono de suas referências culturais e históricas em busca de algo novo, na tentativa de começar a partir de uma tábula rasa, em que as referências culturais não paralisem sua ação.

A Amerika, nesse conto, é sinônimo de uma cultura nova. A propósito de sua mala, o personagem faz uma reflexão muito apropriada ao contexto aqui abordado, quando diz que: "no navio, os hábitos variam conforme os portos. Em Hamburgo, o seu Butterbaum talvez tivesse vigiado a mala, mas aqui, muito provavelmente já não haverá mais rastro de nenhum deles" (KAFKA, 2012, 16). Outro elemento notável encontra-se nas primeiras linhas do conto, quando o personagem se perde ao procurar seu guardachuva. 
Quando ocorre o encontro entre o protagonista e o foguista com o capitão do navio na sala de reuniões, onde estão presentes alguns personagens, incluindo o tio de Karl, o jovem olha distraidamente pela janela. Essa sua visão é bem sintomática da condição humana na contemporaneidade, conforme assinala Tambling, pois representa uma visão fragmentária desse mundo novo, assim como indicada pelo próprio Benjamin.

Eis a cena que Karl contempla pela janela:

\begin{abstract}
Enquanto isso, diante das janelas a vida portuária prosseguia: um cargueiro chato carregado com uma montanha de barris, que deviam estar maravilhosamente bem acondicionados para não rolarem, passou em frente e quase ocasionou o escurecimento completo da cabine; pequenos barcos a motor, que se tivesse tido tempo Karl agora poderia ter observado com mais atenção, deslizavam barulhentos e descreviam linhas absolutamente retas sob o movimento das mãos do homem que se mantinha ereto diante do timão; curiosos objetos flutuantes emergiam aqui e ali espontaneamente das águas inquietas, para serem logo novamente recobertos e submergirem diante dos olhos assombrados; botes de transatlânticos avançavam com marinheiros suando aos remos, repletos de passageiros que, assim como tinham sido colocados ali, permaneciam sentados, quietos e cheios de expectativas, embora alguns deles não conseguissem deixar de girar a cabeça na direção dos cenários cambiantes. Um movimento sem fim, uma inquietação, transposta da inquieta natureza para os desamparados homens e suas obras! (KAFKA, 2012, p. 26).
\end{abstract}

Segundo Tambling, nessa passagem, o sujeito não assume uma posição central na cena, já que a velocidade com que as coisas mudam de figura ou mesmo coexistem mutuamente impedem que se obtenha uma visão mais geral. Não é possível se concentrar em uma única situação, em vista do ritmo frenético com que acontecem, de modo que essa velocidade, como revela Tambling, é a que Benjamin identifica tipicamente no mundo moderno com o advento da fotografia e do cinema. Portanto, a visão de Karl é distraída, logo, sua memória, pelos choques simultâneos dos acontecimentos múltiplos, é atrofiada e incapaz de armazenar os fatos (TAMBLING, 2001, 190-191).

Portanto, a título de conclusão, conjugando com a própria noção de que é possível ser assassinada sem deixar vestígio, tal como Marie Roget no conto policial de Poe interpretado por Benjamin, é similarmente possível desaparecer sem deixar rastros (TAMBLING, 2001, 197). Portanto, a condição de Karl é, por extensão, a do homem contemporâneo, desapropriado de sua capacidade de realizar experiências memoráveis, qual seja, a de se ver destituído de sua própria história e perceber que seu destino é desaparecer da Terra sem deixar vestígios.

Entretanto, assim como a epígrafe indica, a salvação é o que se pode enxergar na catástrofe reinante, pois, em busca de seu horizonte, talvez seja possível realizar a 
redenção do passado no presente, principalmente em uma época que aponta o futuro como algo incerto no mar de naufrágios sob o qual se assentou o século XX. Esses são os momentos de maior perigo, a busca de uma salvação, de um novo sentido que se abrirá no presente. Para isso, é necessária a presença da crítica, da "guardiã do limiar"8 da história humana, pois, diante de uma catástrofe permanente, é somente pela "crítica salvadora" que será possível "libertar o vindouro de sua forma desfigurada, reconhecendo-o no presente. Somente para isso serve a crítica" (BENJAMIN, 2009, 32).

\section{REFERÊNCIAS}

BAUDELAIRE, Charles. As flores do mal. Trad. Ivan Junqueira. Rio de Janeiro: Nova Fronteira, 2015.

Horizonte: Autêntica Editora, 2010.

O pintor da vida moderna. Trad. Tomaz Tadeu. Belo BENJAMIN, Walter. Ankündigung der Zeitschrift: Angelus Novus. In__: Gesammelte Schriften, v. II-1. Frankfurt am Main: Suhrkamp, 2014, p. 242.

A vida dos estudantes. In_: Reflexões sobre a criança, o brinquedo e a educação. São Paulo: Editora 34, 2009, p. 32.

Experiência e pobreza. In_: Obras escolhidas. Magia e técnica. Arte e política. Trad. Sergio Paulo Rouanet. São Paulo: Brasiliense, 2010, p. 114-119.

Franz Kafka. A propósito do décimo aniversário de sua morte. In

Obras escolhidas. Magia e técnica. Arte e política. Trad. Sergio Paulo Rouanet. São Paulo: Brasiliense, 2010, p. 137-164.

O narrador. In_: Obras escolhidas. Magia e técnica. Arte e política. Trad. Sergio Paulo Rouanet. São Paulo: Brasiliense, 2010, p. 197-221.

Paris do Segundo Império. In_: Obras escolhidas III. Charles Baudelaire, um lírico no auge do Capitalismo. Trad. José Carlos Martins Barbosa e Hemerson Alves Baptista. São Paulo: Brasiliense, 2010.

. Passagens. Trad. Irene Aron e Cleonice Paes Barreto Mourão. Belo Horizonte: Editora da UFMG, 2009.

BRECHT. Manual para habitantes de cidades. In_: Poemas. Trad. Paulo César de Souza. São Paulo: Editora 34, 2000.

${ }^{8}$ Cf.: "die Kritik der Hüter der Schwelle" (BENJAMIN, 2014, p. 242). 
FREUD, Sigmund. Psicologia das massas e análise do eu. In_: Obras completas, volume 15. Trad. Paulo César de Souza. São Paulo: Companhia das Letras, 2011, p. 13-99.

HÖLDERLIN, F. Poemas. Trad. Paulo Quintela. Coimbra: Atlântida, 1959.

KAFKA, Franz. O foguista. In _ : O desaparecido ou Amerika. Trad. Susana Kampff Lages. São Paulo: Editora 34, 2012, p. 13-41.

LUKÁCS, G. O fenômeno da reificação. In _: História e consciência de classe. Estudos sobre a dialética marxista. Trad. Rodnei Nascimento. São Paulo: Martins Fontes, 2003, p. 194-240.

POE, Edgar Allan. O homem da multidão. In _: DUFILHO, Jérôme; TADEU, Tomaz (Org.). $O$ pintor da vida moderna. São Paulo: Autêntica, 2010, p. 91-103.

MARX, Karl. A mercadoria. In__: O capital. Livro I. Trad. Rubens Enderle. São Paulo: Boitempo, 2017.

SCHOLEM, G.; ADORNO, T. (edited). The correspondence of Walter Benjamin (19101940). Translated by Manfred R. Jacobscon and Evelyn M. Jacobson. London: University of Chicago, 1994.

TAMBLING, Jeremy. The States and the Statue: Kafka on America. In_: Lost in the American City. Dickens, James and Kafka. Palgrave Macmillan: New York, 2001, p. 181-198.

WEIDMANN, Heiner. Despertar/Sueño. In_ : OPITZ, Michael; WIZISLA, Erdmut (Org.). Conceptos de Walter Benjamin. Trad. María Belforte y Miguel Vedda. Buenos Aires: Las Cuarenta, 2014, p. 305-337. 